\title{
Indium-Mediated Allylation of Carbonyl Compounds in Ionic Liquids: Effect of Salts in Ionic Liquids
}

\author{
Tsunehisa Hirashita * (D), Fusako Takahashi, Takayuki Noda, Yuji Takagi and Shuki Araki \\ Life Science and Applied Chemistry, Graduate School of Engineering, Nagoya Institute of Technology, \\ Gokiso-cho, Showa-ku, Nagoya 466-8555, Japan; f.takahashi.144@nitech.jp (F.T.); t.noda.686@nitech.jp (T.N.); \\ y.takagi.570@nitech.jp (Y.T.); a510224@hotmail.co.jp (S.A.) \\ * Correspondence: hirasita@nitech.ac.jp; Tel.: +81-527-355-626
}

Academic Editors: Akio Baba and Makoto Yasuda

Received: 30 May 2018; Accepted: 10 July 2018; Published: 11 July 2018

\begin{abstract}
The In-mediated allylation of carbonyl compounds can be performed in various types of solvents including ionic liquids. However, we have found that in $[\mathrm{bmim}]\left[\mathrm{BF}_{4}\right]$ (where bmim = 1-butyl-3-methylimidazolium), the In-mediated coupling of crotyl bromide with benzaldehyde gives a complex mixture, and some additives, such as halides and amines, are crucial for the successful conversion to the corresponding $\gamma$-adduct. Instead, the addition of alcohols or water promotes the formation of the $\alpha$-adduct. An asymmetric induction with up to $62 \%$ enantiomeric excess (ee) was observed employing cinchonidine as an additive in a binary solvent consisting of an ionic liquid and dichloromethane.
\end{abstract}

Keywords: indium; allylation; ionic liquids; carbonyl compounds; homoallylic alcohols

\section{Introduction}

Indium-mediated allylations of carbonyl compounds have been extensively studied during the last two decades [1-4]. Allylindium reagents are prepared from metallic indium and allylic halides in a broad range of solvents, including water, and can be used in the Barbier-type allylation of carbonyl compounds. We previously reported the allylation of carbonyl compounds with catalytic amounts of indium(III) trichloride and stoichiometric amounts of aluminum (0) in aqueous tetrahydrofuran [5]. This method provides an easy access to reactions of allylic indium reagents and employs reduced quantities of the relatively expensive indium metal. However, this catalytic allylation proceeds slowly and a couple of days are needed to complete the reaction. More recently, we reported a catalytic variation in a binary solvent system constituted of water and an ionic liquid [6].

Ionic liquids have emerged as recyclable solvents in organic synthesis, and their electrochemical properties have also received attention. The preparation of organometallic compounds in ionic liquids has also been of interest. Grignard reagents, however, have not been prepared in ordinary ionic liquids, and a chelating group such as an ether functionality is required in the ionic liquids to stabilize the Grignard reagents $[7,8]$. The preparation of allylic indium reagents and their reactions with aldehydes [9-12] or imines [13] in ionic liquids have been reported, where the corresponding homoallylic alcohols or homoallylic amines have been obtained in high yields. Noteworthy, the use of ionic liquids possessing chelating units is not required for promoting allylation when allylic indium reagents are involved. Herein, we report that, in contrast to previous results, there are limitations in using ionic liquids for preparing allylic indium reagents, and special additives, including halides, are required in the crotylation of aldehydes depending on the nature of the ionic liquid employed. 


\section{Results and Discussion}

\subsection{Allylation}

We began screening a wide range of ionic liquids to perform the Barbier-type In-mediated allylation. Thus, when allyl bromide and benzaldehyde were mixed with indium powder in [bmim] $\left[\mathrm{BF}_{4}\right]$ (where bmim = 1-butyl-3-methylimidazolium), the corresponding homoallylic alcohol 1 was obtained in good yield and in a shorter time $(5 \mathrm{~h})$ than that previously reported [10] (entry 1, Table 1). The reactions in $[\mathrm{bpy}]\left[\mathrm{BF}_{4}\right]$ (where bpy $=N$-butylpyridinium) and $[\mathrm{bmim}]\left[(\mathrm{CN})_{2} \mathrm{~N}\right]$ also gave 1 in high yields (entries 2 and 3), while the yield decreased in [bmim][OTf] (entry 4). The reaction in $[\mathrm{bmim}][\mathrm{Cl}]$, which was performed under conventional heating as [bmim] [Cl] is not liquid at room temperature, gave $\mathbf{1}$ in low yield (entry 5). The allylation in [bmim][NTf $\left.\mathrm{N}_{2}\right]\left(\mathrm{where}^{\mathrm{b}}\right.$ $\mathrm{NTf}_{2}=$ bis(trifluoromethanesulfonyl)amide) did not proceed (entry 6).

Table 1. Indium-mediated allylation in ionic liquid. ${ }^{a}$

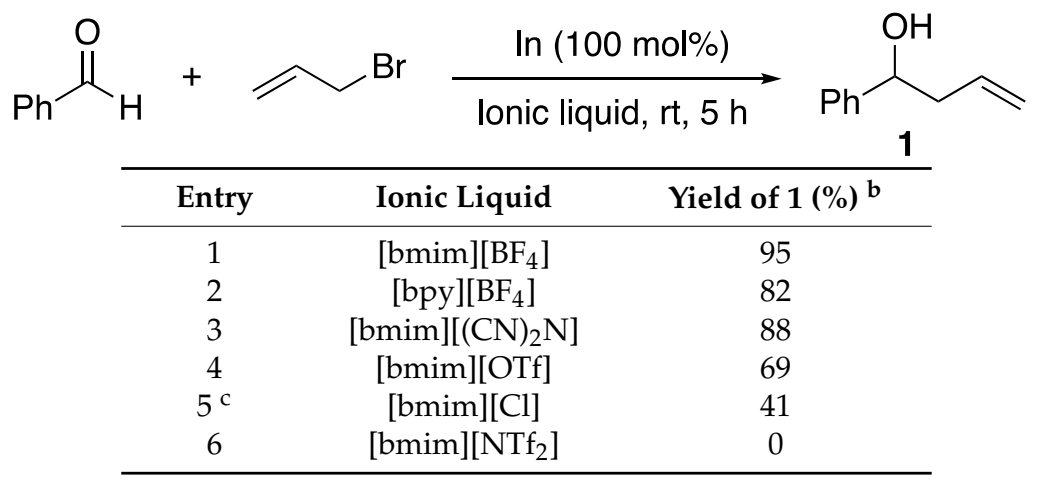

\footnotetext{
a All reactions were carried out with allyl bromide $(1.6 \mathrm{mmol})$, benzaldehyde $(1.0 \mathrm{mmol})$ and indium (1.0 mmol) in ionic liquid $(1.0 \mathrm{~mL})$ at room temperature for $5 \mathrm{~h} ;{ }^{\mathrm{b}} \mathrm{NMR}$ yields determined using 1,3,5-trimethoxybenzene as the internal standard; ${ }^{\mathrm{c}}$ Reaction carried out at $73^{\circ} \mathrm{C}$.
}

We next focused on the allylation involving a reductive transmetalation of a $\pi$-allylpalladium(II) with $\operatorname{In}(\mathrm{I})$, in which a variety of solvents can be used [14]. Among the ionic liquids employed, as above $[\mathrm{bmim}]\left[\mathrm{BF}_{4}\right]$ gave the best yield (entry 1, Table 2). The reactions in $[\mathrm{bpy}]\left[\mathrm{BF}_{4}\right]$ and $[\mathrm{bmim}][\mathrm{OTf}]$ proceeded in moderate yields (entries 2 and 3), while [bmim] $\left[(\mathrm{CN})_{2} \mathrm{~N}\right]$ was not suitable for the allylation (entry 4).

Table 2. Pd-catalyzed indium-mediated allylation in ionic liquid ${ }^{\text {a }}$

\begin{tabular}{|c|c|c|}
\hline \multirow{2}{*}{${ }_{H}^{O}$} & \multicolumn{2}{|c|}{$\begin{array}{l}\text { Inl }(200 \mathrm{~mol} \%) \\
\mathrm{Pd}\left(\mathrm{PPh}_{3}\right)_{4}(5 \mathrm{~mol} \%)\end{array}$} \\
\hline & & Ionic liquid, rt, $24 \mathrm{~h}$ \\
\hline Entry & Ionic Liquid & Yield of $1(\%)^{b}$ \\
\hline 1 & {$[\mathrm{bmim}]\left[\mathrm{BF}_{4}\right]$} & 75 \\
\hline 2 & {$[\mathrm{bpy}]\left[\mathrm{BF}_{4}\right]$} & 61 \\
\hline 3 & [bmim] $][\mathrm{OTf}]$ & 50 \\
\hline 4 & {$[\mathrm{bmim}]\left[(\mathrm{CN})_{2} \mathrm{~N}\right]$} & 16 \\
\hline
\end{tabular}

\footnotetext{
a All reactions were carried out with allyl acetate $(1.0 \mathrm{mmol})$, benzaldehyde $(0.50 \mathrm{mmol})$ and indium(I) iodide $(1.0 \mathrm{mmol})$, and $\mathrm{Pd}\left(\mathrm{PPh}_{3}\right)_{4}(0.025 \mathrm{mmol})$ in ionic liquid $(1.0 \mathrm{~mL})$ at room temperature for $24 \mathrm{~h}$; ${ }^{\mathrm{b}} \mathrm{NMR}$ yields determined using 1,3,5-trimethoxybenzene as the internal standard.
}

\subsection{Crotylation}

We then turned our attention to the crotylation of benzaldehyde. The conversions in $[\mathrm{bmim}]\left[(\mathrm{CN})_{2} \mathrm{~N}\right]$ and $[\mathrm{bmim}][\mathrm{OTf}]$ proceeded well affording homoallylic alcohol 2 in good yields 
(entries 1 and 2, Table 3). Instead, [bmim] $\left[\mathrm{BF}_{4}\right]$, which had proved advantageous in the above reactions (Tables 1 and 2), gave a complicated mixture when used for the coupling of crotyl bromide and benzaldehyde. The ${ }^{1} \mathrm{H}-\mathrm{NMR}$ spectrum of the crude mixture is shown in Figure 1a. As the crotylation in [bmim] $\left[\mathrm{BF}_{4}\right]$ had previously been successful [10], the above result suggests that there are problems associated with the source of the ionic liquid employed. We anticipated that the difference may be caused by some type of impurity present in the ionic liquid, such as [bmim][X] the precursor of [bmim] $\left[\mathrm{BF}_{4}\right]$, which presumably plays an essential role in the allylation of aldehydes as it does in the allylation of imines [13].

Table 3. Crotylation of benzaldehyde in ionic liquid a

\begin{tabular}{cccc} 
& & In $(100 \mathrm{~mol} \%)$ \\
\cline { 3 - 4 } & & Tonic liquid, $\mathrm{rt}$
\end{tabular}

a All reactions were carried out at a $0.5 \mathrm{mmol}$ scale of benzaldehyde at room temperature in ionic liquid ( $1 \mathrm{~mL})$;

${ }^{\mathrm{b}}$ Determined by ${ }^{1} \mathrm{H}-\mathrm{NMR}$ using 1,3,5-trimethoxybenzene as the internal standard; ${ }^{\mathrm{c}}$ Syn:anti.

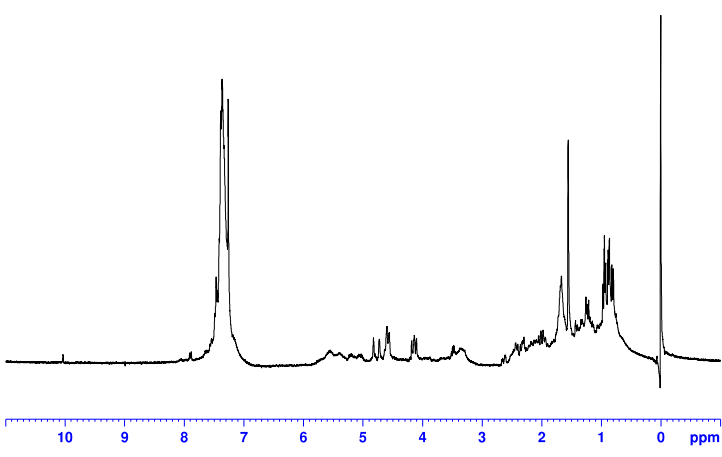

(a) In the absence of $[\mathrm{bmim}][\mathrm{Cl}]$

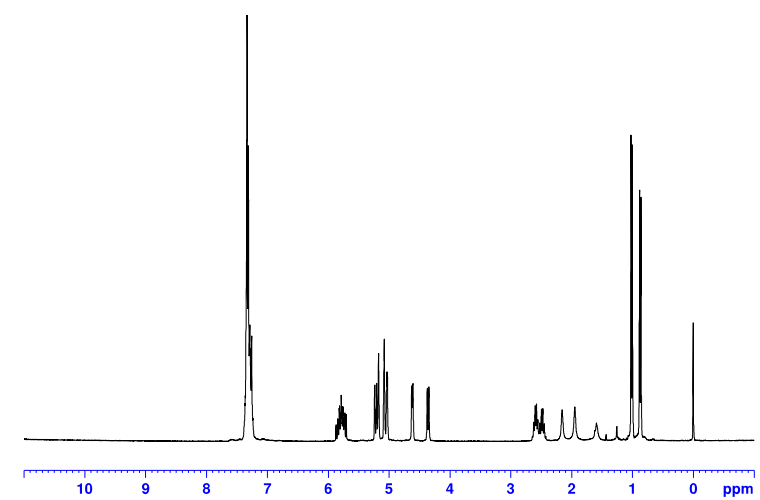

(b) In the presence of $[\mathrm{bmim}][\mathrm{Cl}]$

Figure 1. Crotylation of benzaldehyde in $\left[\mathrm{bmim}^{-}\left[\mathrm{BF}_{4}\right]\right.$ in the absence $(\mathbf{a})$ or presence $(\mathbf{b})$ of $[\mathrm{bmim}][\mathrm{Cl}]$.

We then tested whether the $[\mathrm{bmim}][\mathrm{Cl}]$ residue in $[\mathrm{bmim}]\left[\mathrm{BF}_{4}\right]$ affected the crotylation. When crotyl bromide and benzaldehyde were stirred with indium powder in $[\mathrm{bmim}]\left[\mathrm{BF}_{4}\right]$ containing a small amount of [bmim][Cl], homoallylic alcohol 2 was formed cleanly as depicted in Figure $1 \mathrm{~b}$ (entry 1 , Table 4). In place of [bmim][Cl], $\mathrm{LiCl}$ was next examined to clarify the role of halides. The addition of a stoichiometric amount of $\mathrm{LiCl}$ also improved the yield, giving 2 in high yield (entry 2). The reactions with either a catalytic or excess amount of $\mathrm{LiCl}$ gave lower yields (entries 3 and 4). To get further insights into the role of $\mathrm{LiCl}$ in the mechanism of the reaction, we carried out a set of Grignard-type reactions; thus, a mixture of crotyl bromide and indium in $\left[\mathrm{bmim}^{-}\left[\mathrm{BF}_{4}\right]\right.$ was stirred at room temperature for $0.5 \mathrm{~h}$ in the presence or absence of $\mathrm{LiCl}$ prior to the addition of benzaldehyde. Without $\mathrm{LiCl}$, the reaction did not give homoallylic alcohol 2. Instead, the reaction with $\mathrm{LiCl}$ afforded $\mathbf{2}$ in $97 \%$ yield (Scheme 1). 


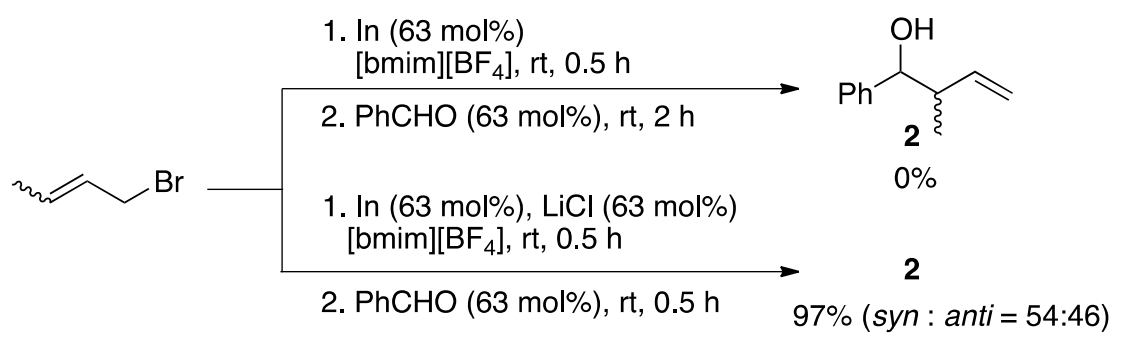

Scheme 1. Effects of $\mathrm{LiCl}$ on the crotylation of benzaldehyde.

During the reaction of crotyl bromide with indium in $[\mathrm{bmim}]\left[\mathrm{BF}_{4}\right]$ in the absence of $\mathrm{LiCl}$, the consumption of indium powder was sluggish and an unidentified solid was deposited [15]. These results demonstrate that $\mathrm{LiCl}$ stabilizes both the crotylindium reagent and the resulting indium homoallylic alkoxide and prevents from unexpected reactions leading to a decreased yield of 2 . The addition of catalytic amounts $(10 \mathrm{~mol} \%)$ of [bmim][Cl], [bmim][Br], or $\mathrm{LiBr}$ was sufficient for a clean formation of $\mathbf{2}$ (entries 5-7), which probably relates to the tendency of these halides to dissociate and their solubility in the media. We next set out to examine other organic/inorganic salts in the crotylation. The addition of triphenylphosphine gave a good yield (entry 8). While a primary alkylamine worked as a promoter to some extent, tertiary amines were less efficient (entries 9 and 10). Pyridine and cinchonidine [16] proved to be good promoters (entries 11 and 12) [17]. Some alcohols, except phenol, promoted the crotylation. However, linear homoallylic alcohol 3 was formed as the major product (entries 13-15). The addition of water also gave a mixture of 2 and 3 (entry 16), indicating that an oxonia[3,3]-sigmatropic rearrangement occurs under these conditions [18].

Table 4. Crotylation of benzaldehyde in the presence of additives ${ }^{\mathrm{a}}$.

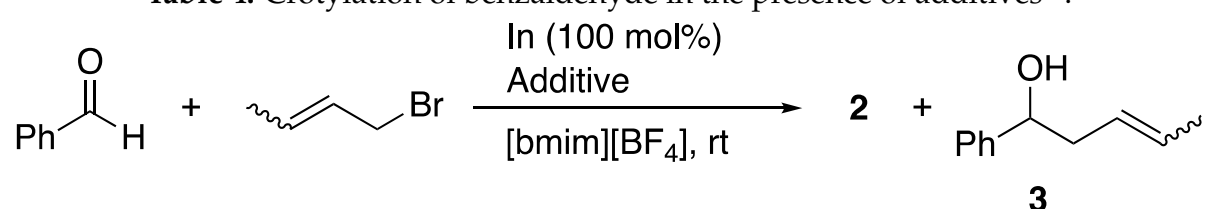

\begin{tabular}{|c|c|c|c|}
\hline Entry & Additive (mol \%) & Time (h) & NMR Yield (\%) (syn:anti) ${ }^{b}$ \\
\hline 1 & {$[\mathrm{bmim}][\mathrm{Cl}](114)$} & 1 & 2: $90(54: 46)$ \\
\hline 2 & $\mathrm{LiCl}(100)$ & 1 & 2: $92(59: 41)$ \\
\hline $3^{c}$ & $\mathrm{LiCl}(10)$ & 1 & 2: $8(66: 34) d$ \\
\hline 4 & $\mathrm{LiCl}(200)$ & 1 & 2: $58(57: 43)$ \\
\hline 5 & {$[\mathrm{bmim}][\mathrm{Cl}](10)$} & 5 & 2: $65(58: 42)$ \\
\hline 6 & {$[\mathrm{bmim}][\mathrm{Br}](10)$} & 5 & 2: $80(63: 37)$ \\
\hline 7 & $\operatorname{LiBr}(10)$ & 1 & 2: $62(63: 37)$ \\
\hline 8 & $\mathrm{PPh}_{3}(100)$ & 2 & 2: $78(56: 44)$ \\
\hline 9 & 1-Butylamine (100) & 3 & 2: $48(58: 42)$ \\
\hline 10 & TMEDA $^{\text {e }}(100)$ & 18 & trace \\
\hline 11 & Pyridine (100) & 6 & 2: $75(57: 43)$ \\
\hline 12 & Cinchonidine (100) & 6 & 2: $82(54: 46)$ \\
\hline 13 & 1-Hexanol (100) & 6 & 2: $26(73: 27)^{d}, 3: 41(47: 53) d, f$ \\
\hline 14 & Phenol (100) & 6 & 0 \\
\hline 15 & Diethyl L-tartrate (100) & 3 & 2: $19(75: 25)^{d}, 3: 33(55: 45) d, f$ \\
\hline 16 & $\mathrm{H}_{2} \mathrm{O}(100)$ & 6 & 2: $45(74: 26)^{d}, 3: 42(48: 52) d, f$ \\
\hline
\end{tabular}

a All reactions were carried out at a $0.5 \mathrm{mmol}$ scale of benzaldehyde at room temperature in [bmim] $\left[\mathrm{BF}_{4}\right]$ $(1 \mathrm{~mL}) ;{ }^{\mathrm{b}}$ 1,3,5-Trimethoxybenzene was used as the internal standard; ${ }^{\mathrm{c}}$ With $1.0 \mathrm{mmol}$ scale; ${ }^{\mathrm{d}}$ Isolated yield;

e Tetramethylethylenediamine; ${ }^{\mathrm{f}} \mathrm{E}: \mathrm{Z}$. 


\subsection{Intramolecular Auxiliary}

As pyridine proved to function as a good promoter, we next employed 2- and 3-pyridinecarboxaldehydes instead of benzaldehyde as substrates of the crotylation reaction in the absence of additives in order to assess the influence of intramolecular interactions between the pyridyl and carbonyl groups (Scheme 2). Although both aldehydes gave the corresponding homoallylic alcohols 4 and 5, 2-pyridinecarboxaldehyde gave a higher yield of the corresponding product than the reaction performed with the 3-pyridinyl isomer. This result suggests that the ring nitrogen atom adjacent to the carbonyl group not only stabilizes the crotylindium reagent and derivatives thereof in [bmim $]\left[\mathrm{BF}_{4}\right]$ but also helps the rapid transformation by intramolecular chelation $[19,20]$.

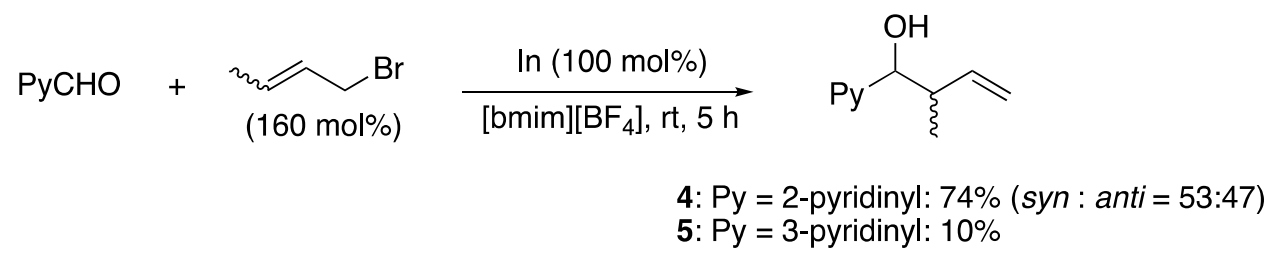

Scheme 2. Effects of intramolecular chelating units.

\subsection{Chiral Auxiliary}

The importance of intra- and intermolecular chelating groups to promote a clean crotylation prompted us to examine an asymmetric version of the present reaction. We anticipated that an asymmetric induction would function well with a judicious choice of chiral additives due to their critical role in promoting the allylation in $[\mathrm{bmim}]\left[\mathrm{BF}_{4}\right]$. As the use of cinchonidine had been reported by Loh and co-workers as a suitable chiral auxiliary for the asymmetric addition of allylindium reagents to aldehydes [21], we set to investigate the effect of cinchonidine on the allylation of benzaldehyde in $[\mathrm{bmim}]\left[\mathrm{BF}_{4}\right]$ under similar conditions to those reported by Loh. After stirring a mixture of allyl bromide and cinchonidine with indium in $[\mathrm{bmim}]\left[\mathrm{BF}_{4}\right]$ for $3 \mathrm{~h}$ at room temperature, benzaldehyde was added. The reaction in $[\mathrm{bmim}]\left[\mathrm{BF}_{4}\right]$ gave a lower yield than that performed without additive (entry 1, Table 1), and a neglectable ee was observed (entry 1, Table 5). We then examined the reaction at low temperature, where the ionic liquid needed to be diluted with an organic solvent due to its high viscosity, and thus, $\mathrm{CH}_{2} \mathrm{Cl}_{2}$ was chosen due to its weakly coordinating character. The reaction in the binary solvent gave a good yield at room temperature with a moderate ee (entry 2), while at $-78^{\circ} \mathrm{C}$ both the yield and ee remarkably decreased (entry 3). At $40{ }^{\circ} \mathrm{C}$, a somewhat higher ee was observed (entry 4). Because cinchonidine is poorly soluble in [bmim][BF 4 , its benzyl ammonium salt was next employed in the reaction (entry 5). This salt completely dissolved and the reaction quickly proceeded, albeit the ee significantly decreased. The reaction in $[\mathrm{bpy}]\left[\mathrm{BF}_{4}\right]$ showed a similar tendency to that found in $[\mathrm{bmim}]\left[\mathrm{BF}_{4}\right]$; the ee value decreased at low temperature (entries 6 and 7). The reaction in a mixture of [bmim] [OTf] and $\mathrm{CH}_{2} \mathrm{Cl}_{2}$ also perceived an improvement both in yield and ee, while the opposite phenomena to that found in $[\mathrm{bmim}]\left[\mathrm{BF}_{4}\right]$ was observed at low temperature, and the ee increased as a result of lowering the temperature (entries 8-11).

Table 5. Asymmetric indium-mediated allylation of benzaldehyde using cinchonidine ${ }^{\mathrm{a}}$.

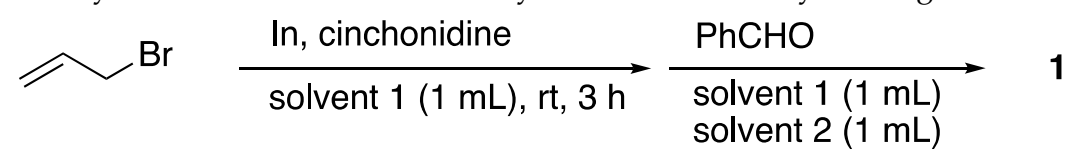

\begin{tabular}{cccccc}
\hline Entry & Solvent Solvent $\mathbf{1} /$ Solvent $\mathbf{2}$ & Temp. $\left({ }^{\circ} \mathbf{C}\right)$ & Time (h) & Yield (\%) & Ee (\%) $\mathbf{b}$ \\
\hline 1 & {$[\mathrm{bmim}]\left[\mathrm{BF}_{4}\right]$} & $\mathrm{rt}$ & 15 & 50 & 2 \\
2 & {$[\mathrm{bmim}]\left[\mathrm{BF}_{4}\right] / \mathrm{CH}_{2} \mathrm{Cl}_{2}$} & $\mathrm{rt}$ & 15 & 90 & 33 \\
3 & {$[\mathrm{bmim}]\left[\mathrm{BF}_{4}\right] / \mathrm{CH}_{2} \mathrm{Cl}_{2}$} & -78 & 15 & 41 & 2 \\
4 & {$[\mathrm{bmim}]\left[\mathrm{BF}_{4}\right] / \mathrm{CH}_{2} \mathrm{Cl}_{2}$} & 40 & 15 & 51 & 20 \\
\hline
\end{tabular}


Table 5. Cont.

\begin{tabular}{cccccc}
\hline Entry & Solvent Solvent 1/Solvent $\mathbf{2}$ & Temp. $\left({ }^{\circ} \mathrm{C}\right)$ & Time (h) & Yield (\%) & Ee (\%) \\
\hline $5^{\mathrm{c}}$ & {$[\mathrm{bmim}]\left[\mathrm{BF}_{4}\right] / \mathrm{CH}_{2} \mathrm{Cl}_{2}$} & $\mathrm{rt}$ & 1 & 81 & 6 \\
6 & {$[\mathrm{bpy}]\left[\mathrm{BF}_{4}\right] / \mathrm{CH}_{2} \mathrm{Cl}_{2}$} & $\mathrm{rt}$ & 15 & 71 & 28 \\
7 & {$[\mathrm{bpy}]\left[\mathrm{BF}_{4}\right] / \mathrm{CH}_{2} \mathrm{Cl}_{2}$} & -60 & 65 & 76 & 3 \\
8 & {$[\mathrm{bmim}][\mathrm{OTf}]$} & $\mathrm{rt}$ & 15 & 81 & 0 \\
9 & {$[\mathrm{bmim}][\mathrm{OTf}] / \mathrm{CH}_{2} \mathrm{Cl}_{2}$} & $\mathrm{rt}$ & 1 & 98 & 51 \\
10 & {$[\mathrm{bmim}][\mathrm{OTf}] / \mathrm{CH}_{2} \mathrm{Cl}_{2}$} & -20 & 15 & 23 & 62 \\
11 & {$[\mathrm{bmim}][\mathrm{OTf}] / \mathrm{CH}_{2} \mathrm{Cl}_{2}$} & -78 & 15 & 34 & 61 \\
\hline
\end{tabular}

a Benzaldehyde (0.25 mmol), allyl bromide (320 mol \%), indium (200 mol \%), and cinchonidine (200 mol \%) were used; ${ }^{b}$ Determined by HPLC; ${ }^{c} N$-Benzylcinchonidium bromide was used instead of cinchonidine.

\section{Materials and Methods}

\subsection{Analysis}

${ }^{1} \mathrm{H}-\mathrm{NMR}$ spectra were recorded on a Varian Mercury spectrometer (300 MHz). Please see the ${ }^{1} \mathrm{H}-\mathrm{NMR}$ of compounds 1-5 in Supplementary Materials. The optical purities of the products were measured by HPLC (Daicel Chiralcel OD-H column). 1-Phenyl-3-buten-1-ol: hexane/ $i-\mathrm{PrOH}=98: 2$, flow rate $1.0 \mathrm{~mL} \min ^{-1}, t_{R}=17.5 \mathrm{~min}(R)$-enantiomer, $t_{R}=20.9 \min (S)$-enantiomer [22]. 2-Methyl-1-phenylbut-3-en-1-ol: hexanes $/ i-\mathrm{PrOH}=99: 1,0.5 \mathrm{~mL} \mathrm{~min}^{-1}, \mathrm{t}_{\mathrm{R}}(S, S$; anti $)=29.9 \mathrm{~min}$, $\mathrm{t}_{\mathrm{R}}(S, R ;$ syn $)=32.2 \mathrm{~min}, \mathrm{t}_{\mathrm{R}}(R, R ;$ anti $)=34.2 \mathrm{~min}, \mathrm{t}_{\mathrm{R}}(R, S ;$ syn $)=35.5 \mathrm{~min}[23]$.

Ionic liquids and indium metal were purchased from commercial sources and used as received. $\mathrm{N}$-Benzylcinchonidium bromide was prepared according to the literature [24]. Allylic bromides and aldehydes were distilled just before use. All reactions were carried out under argon.

\subsection{General Procedure for the Allylation of Benzaldehyde in Ionic Liquids}

A mixture of allyl bromide (138 $\mu \mathrm{L}, 1.6 \mathrm{mmol})$, benzaldehyde $(102 \mu \mathrm{L}, 1.0 \mathrm{mmol})$, and indium $(115 \mathrm{mg}, 1.0 \mathrm{mmol})$ was stirred in ionic liquid $(1.0 \mathrm{~mL})$ at room temperature for $5 \mathrm{~h}$. Water was added to the reaction mixture and the product was extracted with diethyl ether. The extracts were purified by short column chromatography on silica gel. The yield of 1-phenyl-3-buten-1-ol (1) was determined by ${ }^{1} \mathrm{H}$ NMR analysis using 1,3,5-trimethylbenzene as the internal standard.

\subsection{General Procedure for the Pd-Catalyzed Allylation of Benzaldehyde in Ionic Liquids}

A mixture of allyl acetate (108 $\mu \mathrm{L}, 1.0 \mathrm{mmol})$, benzaldehyde $(51 \mu \mathrm{L}, 0.5 \mathrm{mmol})$, indium(I) iodide (424 mg, $1.0 \mathrm{mmol})$, and $\mathrm{Pd}\left(\mathrm{PPh}_{3}\right)_{4}(29 \mathrm{mg}, 0.025 \mathrm{mmol})$ was stirred in ionic liquid $(1.0 \mathrm{~mL})$ at room temperature for $24 \mathrm{~h}$. Dilute hydrochloric acid $(1 \mathrm{M})$ was added to the reaction mixture and the product was extracted with diethyl ether. The organic layer was washed with saturated $\mathrm{NaHCO}_{3}$, water, and brine, and dried over $\mathrm{Na}_{2} \mathrm{SO}_{4}$. The yield of 1-phenyl-3-buten-1-ol (1) was determined by ${ }^{1} \mathrm{H}$ NMR analysis using 1,3,5-trimethylbenzene as the internal standard.

\subsection{General Procedure for the Crotylation of Benzaldehyde in Ionic Liquids}

A mixture of crotyl bromide ( $81 \mu \mathrm{L}, 0.8 \mathrm{mmol})$, benzaldehyde $(51 \mu \mathrm{L}, 0.50 \mathrm{mmol})$, and indium $(58 \mathrm{mg}, 0.50 \mathrm{mmol})$ was stirred in ionic liquid $(1.0 \mathrm{~mL})$ at room temperature for $1 \mathrm{~h}$. Dilute hydrochloric acid $(1 \mathrm{M})$ was added to the reaction mixture and the product was extracted with diethyl ether. The organic layer was washed with saturated $\mathrm{NaHCO}_{3}$, water, and brine, and dried over $\mathrm{Na}_{2} \mathrm{SO}_{4}$. The yield of 2 was determined by ${ }^{1} \mathrm{H}$-NMR analysis using 1,3,5-trimethylbenzene as the internal standard.

\subsection{Crotylation of Benzaldehyde in the Presence of Additives}

A mixture of crotyl bromide $(81 \mu \mathrm{L}, 0.80 \mathrm{mmol})$, benzaldehyde $(58 \mu \mathrm{L}, 0.50 \mathrm{mmol})$, indium $(58 \mathrm{mg}, 0.50 \mathrm{mmol})$, and additive was stirred in $[\mathrm{bmim}]\left[\mathrm{BF}_{4}\right](1.0 \mathrm{~mL})$ at room temperature for $1 \mathrm{~h}$. 
Dilute hydrochloric acid $(1 \mathrm{M})$ was added to the reaction mixture and the product was extracted with diethyl ether. The organic layer was washed with saturated $\mathrm{NaHCO}_{3}$, water, and brine, and dried over $\mathrm{Na}_{2} \mathrm{SO}_{4}$. The yield of 2 was determined by ${ }^{1} \mathrm{H}$ NMR analysis using 1,3,5-trimethylbenzene as the internal standard.

\subsection{General Procedure for the Asymmetric Indium-Mediated Allylation of Benzaldehyde Using Cinchonidine}

The reaction in entry 10 is described as a representative typical procedure. A mixture of allyl bromide ( $69 \mu \mathrm{L}, 0.8 \mathrm{mmol})$, indium $(58 \mathrm{mg}, 0.50 \mathrm{mmol})$, and cinchonidine $(147 \mathrm{mg}, 0.50 \mathrm{mmol})$ was stirred in [bmim][OTf] $(1.0 \mathrm{~mL})$ at room temperature for $3 \mathrm{~h}$. To the resulting mixture a solution of benzaldehyde $(25 \mu \mathrm{L}, 0.25 \mathrm{mmol})$ in $\mathrm{CH}_{2} \mathrm{Cl}_{2}(1 \mathrm{~mL})$ was added and the mixture was stirred at $-78^{\circ} \mathrm{C}$ for another $15 \mathrm{~h}$. The mixture was quenched with dilute hydrochloric acid $(1 \mathrm{M}, 2 \mathrm{~mL})$ and the product extracted with diethyl ether. The organic layer was washed with saturated $\mathrm{NaHCO}_{3}$, water, and brine, and dried over $\mathrm{Na}_{2} \mathrm{SO}_{4}$. The solvent was removed under reduced pressure to give a slightly yellow oil. The yield of 1-phenyl-3-buten-1-ol (1) was determined by ${ }^{1} \mathrm{H}-\mathrm{NMR}$ analysis using 1,3,5-trimethylbenzene as the internal standard (34\%), and the ee for $(R)-\mathbf{1}$ was determined by HPLC analysis (61\%).

\subsection{Product Characterization}

1-Phenyl-3-buten-1-ol (1) [22]. ${ }^{1} \mathrm{H}-\mathrm{NMR}\left(300 \mathrm{MHz}, \mathrm{CDCl}_{3}\right)$ : $\delta 2.05$ (brs, 1H), 2.47-2.57 (m, 2H), 4.72-4.77 $(\mathrm{q}, J=7.5 \mathrm{~Hz}, 1 \mathrm{H}), 5.12-5.20(\mathrm{~m}, 2 \mathrm{H}), 5.75-5.89(\mathrm{~m}, 1 \mathrm{H}), 7.25-7.37(\mathrm{~m}, 5 \mathrm{H})$.

2-Methyl-1-phenyl-3-buten-1-ol (2) [25]. ${ }^{1} \mathrm{H}-\mathrm{NMR}\left(300 \mathrm{MHz}, \mathrm{CDCl}_{3}\right)$ syn isomer: $\delta 1.01(\mathrm{~d}, J=6.6 \mathrm{~Hz}$, $3 \mathrm{H}), 1.93$ (brs, $1 \mathrm{H}), 2.45-2.62(\mathrm{~m}, 1 \mathrm{H}), 4.62(\mathrm{~d}, J=4.8 \mathrm{~Hz}, 1 \mathrm{H}), 5.04-5.08(\mathrm{~m}, 2 \mathrm{H}), 5.71-5.88(\mathrm{~m}, 1 \mathrm{H})$, 7.26-7.337 (m, 5H); anti isomer: $\delta 0.87(\mathrm{~d}, J=6.9 \mathrm{~Hz}, 3 \mathrm{H}), 1.93(\mathrm{bs}, 1 \mathrm{H}), 4.36(\mathrm{~d}, J=5.2 \mathrm{~Hz}, 1 \mathrm{H}), 5.17-5.24$ $(\mathrm{m}, 1 \mathrm{H})$.

1-Phenyl-3-penten-1-ol (3) [18]. ${ }^{1} \mathrm{H}-\mathrm{NMR}\left(300 \mathrm{MHz}, \mathrm{CDCl}_{3}\right)(E)$ - isomer: $\delta 1.61(\mathrm{dd}, J=6.8,0.8 \mathrm{~Hz}$, $3 \mathrm{H}), 2.00(\mathrm{~s}, 1 \mathrm{H}), 2.34-2.63(\mathrm{~m}, 2 \mathrm{H}), 4.66-4.75(\mathrm{~m}, 1 \mathrm{H}), 5.38-5.47(\mathrm{~m}, 1 \mathrm{H}), 5.55-5.68(\mathrm{~m}, 1 \mathrm{H}), 7.26-7.39$ (m, 5H); (Z)- isomer: $\delta 1.69(\mathrm{dd}, J=6.2 \mathrm{~Hz}, 0.9 \mathrm{~Hz}, 3 \mathrm{H}), 2.06(\mathrm{~s}, 1 \mathrm{H})$.

2-Methyl-1-(2-pyridinyl)-3-buten-1-ol (4) [20]. ${ }^{1} \mathrm{H}-\mathrm{NMR}\left(300 \mathrm{MHz}, \mathrm{CDCl}_{3}\right)$ syn isomer: $\delta 0.91$ $(\mathrm{d}, J=6.9 \mathrm{~Hz}, 3 \mathrm{H}), 2.57-2.73(\mathrm{~m}, 1 \mathrm{H}), 4.12(\mathrm{t}, J=6.3 \mathrm{~Hz}, 1 \mathrm{H}), 4.71(\mathrm{t}, J=4.8 \mathrm{~Hz}, 1 \mathrm{H}), 5.00-5.10$ $(\mathrm{m}, 2 \mathrm{H}), 5.86-5.99(\mathrm{~m}, 1 \mathrm{H}), 7.18-7.26(\mathrm{~m}, 2 \mathrm{H}), 7.67(\mathrm{t}, J=7.8 \mathrm{~Hz}, 1 \mathrm{H}), 8.55(\mathrm{~d}, J=4.8 \mathrm{~Hz}, 1 \mathrm{H})$; anti isomer: $\delta 1.08(\mathrm{~d}, J=6.9 \mathrm{~Hz}, 3 \mathrm{H}), 4.64(\mathrm{t}, J=4.8 \mathrm{~Hz}, 1 \mathrm{H}), 5.69-5.81(\mathrm{~m}, 1 \mathrm{H})$.

2-Methyl-1-(3-pyridinyl)-3-buten-1-ol (5) [26]. ${ }^{1} \mathrm{H}-\mathrm{NMR}\left(300 \mathrm{MHz}, \mathrm{CDCl}_{3}\right)$ syn isomer: $\delta 0.91$ $(\mathrm{d}, J=6.9 \mathrm{~Hz}, 3 \mathrm{H}), 2.48$ (sext, $J=7.5 \mathrm{~Hz}, 1 \mathrm{H}), 4.43(\mathrm{~d}, J=7.5 \mathrm{~Hz}, 1 \mathrm{H}), 5.03-5.11(\mathrm{~m}, 1 \mathrm{H}), 5.18-5.23$ (m, $1 \mathrm{H}), 5.70-5.85(\mathrm{~m}, 1 \mathrm{H}), 7.27-7.30(\mathrm{~m}, 1 \mathrm{H}), 7.65-7.71(\mathrm{~m}, 1 \mathrm{H}), 8.53$ (brs, $2 \mathrm{H})$; anti isomer: $\delta 1.02$ $(\mathrm{d}, J=6.6 \mathrm{~Hz}, 3 \mathrm{H}), 2.60(\mathrm{sext}, J=6.6 \mathrm{~Hz}, 1 \mathrm{H}), 4.67(\mathrm{~d}, J=5.4 \mathrm{~Hz}, 1 \mathrm{H})$.

\section{Conclusions}

The choice of ionic liquid is important to achieve a clean In-mediated allylation and crotylation of carbonyl compounds. From a screening of ionic liquids, $[\mathrm{bmim}]\left[\mathrm{BF}_{4}\right]$ was found to be the most promising solvent for both the In-promoted couplings of allyl bromide to carbonyl compounds and the Pd-catalyzed In(I)-mediated version. Instead, when crotyl bromide is employed, the use of pure [bmim $]\left[\mathrm{BF}_{4}\right]$ has detrimental effects, and the addition of appropriate halide salts or amines is crucial for a successful crotylation leading to the $\gamma$-adduct. Instead, the addition of alcohols and water in [bmim] $\left[\mathrm{BF}_{4}\right]$ favor the formation of the $\alpha$-adduct isomer. Furthermore, cinchonidine functions as a chiral promoter in the coupling of allyl bromide and benzaldehyde in $[\mathrm{bmim}]\left[\mathrm{BF}_{4}\right] / \mathrm{CH}_{2} \mathrm{Cl}_{2}$, affording the corresponding homoallylic alcohol with up to $62 \%$ ee. 
Supplementary Materials: The following are available online. ${ }^{1} \mathrm{H}-\mathrm{NMR}$ of compounds 1-5.

Author Contributions: T.H. and S.A. conceived and designed the experiments; F.T., T.N., and Y.T. performed the experiments and analyzed the data; T.H. wrote the paper.

Funding: This research received no external funding.

Conflicts of Interest: The authors declare no conflicts of interest.

\section{References and Notes}

1. Araki, S.; Hirashita, T. Comprehensive Organometallic Chemistry III; Crabtree, R., Mingos, M., Eds.; Elsevier: Oxford, UK, 2007; pp. 649-751. ISBN 978-0-08-045047-6.

2. Yadav, J.S.; Antony, A.; George, J.; Subba Reddy, B.V. Recent Developments in Indium Metal and Its Salts in Organic Synthesis. Eur. J. Org. Chem. 2010, 591-605. [CrossRef]

3. Roy, U.K.; Roy, S. Making and Breaking of Sn-C and In-C Bonds in Situ: The Cases of Allyltins and Allylindiums. Chem. Rev. 2010, 110, 2472-2535. [CrossRef] [PubMed]

4. Kim, S.H.; Lee, H.S.; Kim, K.H.; Kim, S.H.; Kim, J.N. Recent advances in allylindium reagents in organic synthesis. Tetrahedron 2010, 66, 7065-7076. [CrossRef]

5. Araki, S.; Jin, S.-J.; Idou, Y.; Butsugan, Y. Allylation of Carbonyl Compounds with Catalytic Amount of Indium. Bull. Chem. Soc. Jpn. 1992, 65, 1736-1738. [CrossRef]

6. Hirashita, T.; Sato, Y.; Yamada, D.; Takahashi, F.; Araki, S. Ionic Liquid-accelerated Allylation of Carbonyl Compounds with a Catalytic Amount of Indium Generated From in Situ Reduction of $\mathrm{InCl}_{3}$ with Aluminium. Chem. Lett. 2011, 40, 506-507. [CrossRef]

7. Law, M.C.; Wong, K.-Y.; Chan, T.H. Grignard Reagents in Ionic Liquids. Chem. Commun. 2006, $2457-2459$. [CrossRef] [PubMed]

8. Ford, L.; Atefi, F.; Singer, R.D.; Scammells, P.J. Grignard Reactions in Pyridinium and Phosphonium Ionic Liquids. Eur. J. Org. Chem. 2011, 2011, 942-950. [CrossRef]

9. Gordon, C.M.; Ritchie, C. Indium and Tin-Mediated Allylation in Ionic Liquids. Green Chem. 2002, 4, $124-128$. [CrossRef]

10. Law, M.C.; Wong, K.-Y.; Chan, T.H. Metal Mediated Allylation of Carbonyl Compounds in Ionic Liquids. Green Chem. 2002, 4, 161-164. [CrossRef]

11. Bowyer, M.C.; Gordon, C.M.; Leitch, S.K.; McCluskey, A.; Ritchie, C. Indium-mediated Addition of 4-Bromocrotonic Acid to Aldehydes and Ketones-A Simple, High Yielding Route to $\alpha$-Allyl- $\beta$-hydroxy Carboxylic Acids. Aust. J. Chem. 2004, 57, 135-137. [CrossRef]

12. Dey, P.; Koli, M.; Goswami, D.; Sharma, A.; Chattopadhyay, S. [bmim][Br] as an Inexpensive and Efficient Medium for the Barbier-Type Allylation Reaction Using a Catalytic Amount of Indium: Mechanistic Studies. Eur. J. Org. Chem. 2018, 2018, 1333-1341. [CrossRef]

13. Law, M.C.; Cheung, T.W.; Wong, K.Y.; Chan, T.H. Synthetic and Mechanistic Studies of Indium-Mediated Allylation of Imines in Ionic Liquids. J. Org. Chem. 2007, 72, 923-929. [CrossRef] [PubMed]

14. Araki, S.; Kamei, T.; Hirashita, T.; Yamamura, H.; Kawai, M. A New Preparative Method for Allylic Indium(III) Reagents by Reductive Transmetalation of $\pi$-Allylpalladium(II) with Indium(I) Salts. Org. Lett. 2000, 2, 847-849. [CrossRef] [PubMed]

15. Soengas, R.G.; Silva, V.L.M.; Pinto, J.; Rodríguez-Solla, H.; Silva, A.M.S. Ohmic Heating and Ionic Liquids in Combination for the Indium-Promoted Synthesis of 1-Halo Alkenyl Compounds: Applications to Pd-Catalysed Cross-Coupling Reactions. Eur. J. Org. Chem. 2016, 2016, 99-107. [CrossRef]

16. The ee values of the syn and anti diastereomers were both $5 \%$.

17. One of the reviewers suggested a possibility that both crotylindium species and carbonyl compounds are activated by additives.

18. Tan, K.-T.; Chng, S.-S.; Cheng, H.-S.; Loh, T.-P. Development of a Highly $\alpha$-Regioselective Metal-mediated Allylation Reaction in Aqueous Media: New Mechanistic Proposal for the Origin of $\alpha$-Homoallylic Alcohols. J. Am. Chem. Soc. 2003, 125, 2958-2963. [CrossRef] [PubMed]

19. Paquette, L.A.; Rothhaar, R.R. Competitive Intramolecular/Intermolecular Chelation Options Operative during Indium-Promoted Additions to Pyridyl Aldehydes and to Glyoxylic Acid under Aqueous Conditions. J. Org. Chem. 1999, 64, 217-224. [CrossRef] [PubMed] 
20. Hirashita, T.; Kamei, T.; Satake, M.; Horie, T.; Shimizu, H.; Araki, S. Control of Diastereoselectivity in the Crotylation and Cinnamylation of Aldehydes by the Selection of Ligands on Allylic Indium Reagents. Org. Biomol. Chem. 2003, 1, 3799-3803. [CrossRef] [PubMed]

21. Loh, T.-P.; Zhou, J.-R.; Yin, Z. A Highly Enantioselective Indium-Mediated Allylation Reaction of Aldehydes. Org. Lett. 1999, 11, 1855-1857. [CrossRef]

22. Kim, I.S.; Ngai, M.-Y.; Krische, M.J. Enantioselective Iridium-catalyzed Carbonyl Allylation from the Aalcohol or Aldehyde Oxidation Level Using Allyl Acetate as an Allyl Metal Surrogate. J. Am. Chem. Soc. 2008, 130, 6340-6341. [CrossRef] [PubMed]

23. Kim, I.S.; Han, S.B.; Krischa, M.J. anti-Diastereo- and Enantioselective Carbonyl Crotylation from the Alcohol or Aldehyde Oxidation Level Employing a Cyclometallated Iridium Catalyst: $\alpha$-Methyl Allyl Acetate as a Surrogate to Preformed Crotylmetal Reagents. J. Am. Chem. Soc. 2009, 131, 2514-2520. [CrossRef] [PubMed]

24. Tao, Z.; Adele, A.; Wu, X.; Gong, L. A Highly Enantioselective Mannich-Type Reaction of Glycine Schiff Base Catalyzed by a Cinchoninium Salt. Chin. J. Chem. 2014, 32, 969-973. [CrossRef]

25. Reilly, M.K.; Rychnovsky, S.D. Allyl Transfer to Aldehydes and Ketones by Brønsted Acid Activation of Allyl and Crotyl 1,3,2-Dioxazaborolidines. Org. Lett. 2010, 12, 4892-4895. [CrossRef] [PubMed]

26. Fujimoto, K.; Sakai, H.; Nakai, T. [2,3]-Wittig Rearrangement of Crotyl Picolyl Ethers. Evaluation of the Electronic Effect as a Stereo-Directing Factor. Chem. Lett. 1993, 8, 1397-1400. [CrossRef]

Sample Availability: Not available. 